\title{
Tadalafil and its effects in renal function after kidney ischemia and reperfusion in rats
}

Tadalafil e seus efeitos na função renal após isquemia e reperfusão do rim em ratos.

Ana Luisa Souza Leandro de Carvalho, Nina Amanda Borges de Araújo, Raquel Holanda de Lima, Renata Bezerra Menezes, Paulo José de Medeiros, Aldo Cunha Medeiros

\footnotetext{
Study performed at Department of Surgery, Federal University of Rio Grande do Norte (UFRN), Brazil.

Scientific Initiation Program

Financial support: none.

Conflict of interest: None.

Correspondence address: Department of Surgery, Federal University of Rio Grande do Norte, at Ave. Nilo Peçanha 620, Natal, RN, Brazil, E-mail: cirurgex.ufrn@gmail.com

Submitted: April 10, 2015. Accepted, after review: August 3, 2015.
}

\begin{abstract}
Background/purpose: Renal ischemia/reperfusion (I/R) occurs in kidney transplantation and in partial nephrectomyes and it may result in acute tubular necrosis and other postoperative complications. We hypothesized that administration of tadalafil may attenuate circulating inflammatory biomarkers and improve fasting plasma urea, creatinine and C-reactive protein after renal ischemia/reperfusion injury in rats. Methods: two groups of Wistar rats we used, both underwent right nephrectomy. Group I/R saline rats $(n=6)$ were subjected to 30 minutes of renal ischemia by clamping the left renal artery and treated with saline; the I/R tadalafil rats $(n=6)$ received $10 \mathrm{mg} / \mathrm{kg}$ tadalafil by gavage one hour before ischemia. 24 hours after ischemia, laboratory analysis were performed. Results: The anti-inflammatory cytokine IL-10 was increased in the $\mathrm{I} / \mathrm{R}$ tadalafil $(152.8 \pm 6.8 \mathrm{pg} / \mathrm{dL}$ ) rats, compared to I/R saline $(53.5 \pm 5.2)(p<0.001)$. TNF- $\alpha$ level was significantly lower in I/R tadalafil group rats compared to I/R saline group ( $267 \pm 11.5 \mathrm{vs.}$ $405.3 \pm 12.3)$, as well as IL-1 $\beta(160.4 \pm 12.3$ vs $274 \pm 18.4 \mathrm{pg} / \mathrm{dL}$, respectively; $P=0.0001)$ Conclusion: We have provided evidence that tadalafil therapy ameliorates circulating pro-inflammatory cytokines in a renal I/R rodent model, while improving kidney function proofs levels and reducing C-reactive protein. Further trials may lead to potential clinical application of tadalafil in cases of renal I/R.
\end{abstract}

Key words: Ischemia. Reperfusion. Kidney. Tadalafil. Rats.

\section{RESUMO}

Introdução/Objetivo: $\mathrm{A}$ isquemia/reperfusão renal ocorre nos transplantes renais e nas nefrectomias parciais, podendo resultar em necrose tubular aguda e outras complicações 
pós-operatórias. O presente estudo teve o objetivo de analisar se o tratamento com tadalafil pode atenuar os níveis de biomarcadores inflamatórios e melhorar provas de função renalapós isquemia/reperfusão do rim em ratos. Métodos: foram utilizados dois grupos de animais, ambos submetidos previamente a nefrectomia direita. No grupo I/R salina $(n=6)$ ratos Wistar foram submetidos a 30 minutos de isquemia renal por clampeamento de artéria renal esquerda e tratados com salina; no grupo $\mathrm{I} / \mathrm{R}$ tadalafil $(\mathrm{n}=6)$ os animais receberam $10 \mathrm{mg} / \mathrm{Kg}$ de tadalafil uma hora antes da isquemia, por gavagem. 24 horas após isquemia, dosagens plasmáticas foram realizadas. Resultados: O nível plasmático da citocina antiinflamatória $\mathrm{IL}-10$ foi maior no grupo de ratos $\mathrm{I} / \mathrm{R}$ tadalafil $(152,8 \pm 8,06 \mathrm{pg} / \mathrm{dL})$ quando comparado com 0 grupo $\mathrm{I} / \mathrm{R}$ salina $(53,5 \pm 5.2)$, $(p<0,001)$. O nível de TNF- $\alpha$ foi significativamente menor no grupo de ratos $\mathrm{I} / \mathrm{R}$ tadalafil quando comparado com o grupo $\mathrm{I} / \mathrm{R}$ salina ( $267 \pm 11,5$ vs. $405,3 \pm 12,3)$, do mesmo modo que a IL-1 $\beta(160,4 \pm 12,3$ vs $274 \pm 18,4 \mathrm{pg} / \mathrm{dL}$, respectivamente; $\mathrm{p}=0,0001)$. Conclusão: Ficou evidenciado que o tratamento com tadalafil reduziu a expressão das citocinas proinflamatórias circulantes em modelo de I/R renal em ratos, enquanto que melhorou as provas de função renal e os níveis de proteína- $C$ reativa. Tornam-se necessários futuros ensaios que possam avaliar o potencial de aplicação clínica do tadalafil em casos de I/R renal.

Descritores: Isquemia. Reperfusão. Rim Tadalafil. Ratos.

\section{INTRODUCTION}

Renal injury caused by ischemia/reperfusion $(\mathrm{I} / \mathrm{R})$ inevitably occurs in surgical procedures in which the kidneys remain without receiving blood supply. It is observed during renal transplantation, vascular surgery of the aorta and renal arteries and partial nephrectomy. In renal transplantation, the graft dysfunction, acute rejection and chronic kidney disease correlate with the degree of ischemic injury and increases with the presence of normothermic ischemia, especially when the kidneys are from donors heart arrest ${ }^{1}$. In partial nephrectomy, although the objective is to preserve kidney function, injury by $\mathrm{I} / \mathrm{R}$ often occurs in the remaining renal tissue due to the temporary clamping of the renal artery, performed in order to avoid bleeding, and to permit adequate visualization of organs and tissues ${ }^{2,3}$.

The reperfusion is the main responsible for tissue injury during transplantation, after the kidney go through a period of ischemia. After renal transplantation this is the most common situation of such injury ${ }^{4}$. The pathophysiology of this injury is explained by the production of oxygen free radicals after reoxygenation, which initiates a cascade of apoptosis and tissue necrosis, with local inflammation, cell death and subsequent organ failure. The damage depends on the ischemic period, time when cells spend without oxygenation ${ }^{5}$. 
In cases of partial nephrectomy, endothelial injury causes changes in vascular responses to vasoactive substances ${ }^{6}$. Ischemia causes increased vascular resistance by the loss of the ability of renal vascular endothelium to produce nitric oxide, and thus an imbalance in the production of endothelin-1/nitric oxide, essential for the function that regulates the organ vascular perfusion, since the lower nitric oxide (NO) production will cease to inhibit the expression of endothelin-1 gene, which is a vasoconstrictor. Thus, higher levels of vascular resistance have been associated with a higher percentage of early renal graft dysfunction and even shorter survival ${ }^{7,8}$. Furthermore, ischemic injury promotes the infiltration of neutrophils and mononuclear cells, and this has been associated with the progression of tissue injury ${ }^{9}$.

In order to protect the organs from the effects of $I / R$, various substances have been used in experimental studies, many of them related to the performance of $\mathrm{NO}^{10}$. In the last two decades, the attention has turned to phosphodiesterase type 5 inhibitors which increase the concentration of cyclic guanosine 3,5-monophosphate (cGMP) resulting in release of $\mathrm{NO}$, and thus indirectly causing arterial vasodilation ${ }^{10}$.

Sildenafil is a potent inhibitor of phosphodiesterase-5, enzyme which degrades cGMP in smooth muscle cells that with the increase of cGMP receives less calcium ions from the external environment, which causes the relaxation of the muscle cell and prolonged vasodilation. Studies have demonstrated the presence of phosphodiesterase- 5 in smooth muscle of vessels, bronchi and also in platelets ${ }^{11}$. The use of sildenafil proved protective against endothelial dysfunction in the transplanted heart, and a hemodynamic improvement in self-transplanted kidneys have been shown in pre-conditioned animals with sildenafil, for increasing glomerular filtration rate by reducing the vascular resistance due vasodilation of efferent arterioles ${ }^{12,13}$. The effect of sildenafil in ischemia/reperfusion injury procedure has been studied. Sildenafil contributes to the early recovery of the heart debt after ischemia, and reduces the extent of the infarcted area. Thus, it is possible that can be used to prevent further damage in cardiac surgery using cardiopulmonary bypass, with pauses in breathing or even in children with congenital heart disease who have low blood flow ${ }^{14}$.

A previous study in our laboratory demonstrated that sildenafil has a positive effect on $\mathrm{I} / \mathrm{R}$ of kidney when administered one hour before renal ischemia. This positive effect was shown by a lower area of cellular necrosis, as evaluated by radionuclide imaging and histopathology ${ }^{15}$. 
There have been few studies on the effects of tadalafil on kidney ischemia and reperfusion ${ }^{16-22}$. So, we designed this study that aims to evaluate the effects of tadalafil in the prevention of kidney injury after normothermic renal ischemia/reperfusion in rats.

\section{METHODS}

Twelve male Wistar (Rattus norvegicus) rats weighing $280 \pm 27 g$ were used, provided by the vivarium of the Center for Health Sciences, Federal University of Rio Grande do Norte, Brazil. All animals were distributed in individual cages with water and rodent feed (Presence $\AA$ ) ad libitum and acclimatized in the laboratory for 7 days. They were kept under temperature control $\left(21^{\circ} \mathrm{C}\right)$, humidity $(60-70 \%), 12 / 12$ hours light/dark cycle, and handled in accordance with the precepts of ethics in animal experiments required by the Brazilian Law no. 11794/08. This project was approved by the institutional Ethics Committee on Animal Use. The animals were randomly distributed into 02 groups of 06 each and anesthetized with Xylazine $(10 \mathrm{mg} / \mathrm{kg})$ and Ketamine $(70 \mathrm{mg} / \mathrm{kg})$ intraperitoneally. All surgical procedures were performed by experienced surgeon in experimental surgery using aseptic technique.

An abdominal median laparotomy was conducted, proceeding to right nephrectomy and isolation of the left renal artery. I/R saline group: The left kidney artery was clamped for 30 minutes with a nontraumatic microvascular bulldog clamp, and the kidney was subjected to ischemia. Following ischemia, the left kidney artery clamp was removed, and the kidney was perfused for 24 hours. I/R tadalafil group: One hour before subjecting the rat to ischemia, a $1 \mathrm{~mL}$ microemulsion of $10 \mathrm{mg} / \mathrm{kg}$ tadalafil was injected orally by gavage. Then, the left kidney pedicle was clamped for $30 \mathrm{~min}$, as described for the I/R saline group. Following ischemia, the left kidney was subjected to 24-hour reperfusion by removing the clamp from the left artery.

During surgery $05 \mathrm{ml}$ of $0.9 \%$ saline were injected in the peritoneal cavity, and $5 \mathrm{ml}$ subcutaneously in the immediate postoperative period for hydration. The abdominal wall was closed in layers with nylon 4-0. Postoperative pain was controlled with meperidine 10 $\mathrm{mg} / \mathrm{kg}$ subcutaneously every 12 hours.

\section{Measurement of plasma inflammatory cytokines and biochemistry}

After observation for 24 hs the rats were anesthetized again and a $5 \mathrm{~mL}$ blood sample was collected by cardiac puncture into 2 separate ethylenediamine-tetraacetic acid (EDTA) tubes, stored immediately on ice and centrifuged at 3,000 rpm for 10 minutes. The plasma was separated and stored at $-40^{\circ} \mathrm{C}$ until analysis. Plasma 
concentrations of representative cytokines IL-10, TNF- $\alpha$ and IL-1 $\beta$ were quantified using ELISA assay kits (PeproTec, USA). Plasma samples were used to measure urea, creatinine and C-reative protein using commercially available colorimetric assay kits. The biochemical analysis were performed using autoanalyzer (Weiner Lab BT Plus 3000) and spectrophotometer Konelab 60i, (kit da Weiner, São Paulo, Brazil). After that, rats were euthanased with overdose of thiopental (100mg/Kg i.p.).

The statistical analyses were carried out using BioEstat 5.0 software. The Student $t$ test was used to compare laboratory data. A value of $p<0.05$ indicated statistical significance.

\section{RESULTS}

\section{Plasma Inflammatory Cytokine Levels}

The anti-inflammatory cytokine IL-10 was increased in the tadalafil $(152.8 \pm 8.06$ $\mathrm{pg} / \mathrm{dL})$ treated rats as compared to saline-treated (53.5 \pm 5.2$),(p<0.001, n=6 / g r o u p ;$ Table 1). Pro-inflammatory cytokines were decreased when measured in rats treated with tadalafil, when compared to the saline-treated rats (Table 1). TNF- $\alpha$ was significantly reduced compared to saline-control ( $267 \pm 11.56$ vs. $405.3 \pm 12.3)$, as well as IL-1 $\beta$ ( $160.4 \pm 12.3$ vs $274 \pm 18.4 \mathrm{pg} / \mathrm{dL}$, respectively; $\mathrm{p}=0.0001)$.

Table 1 - Data of comparative cytokines in renal I/R rats treated and untreated with tadalafil.

\begin{tabular}{lccc}
\hline \multirow{2}{*}{ Parameters } & \multicolumn{2}{c}{ Groups } & p-value \\
\cline { 2 - 3 } & I/R Saline & I/R tadalafil & \\
\hline IL-10 & $53.5 \pm 5.2$ & $152.8 \pm 8.6$ & 0.001 \\
TNF $(\mathrm{pg} / \mathrm{dl})$ & $405.3 \pm 12.3$ & $267 \pm 11.5$ & 0.0001 \\
$\mathrm{IL}-1 \beta(\mathrm{pg} / \mathrm{dL})$ & $274 \pm 18.4$ & $160.4 \pm 12.3$ & 0.0001 \\
\hline
\end{tabular}

Values in mean \pm standard deviation

Fasting plasma urea, creatinine and C-reactive protein levels were measured upon completion of therapy. I/R Wistar rats treated with tadalafil showed a significant decrease in fasting plasma urea, creatinine and C-reactive protein, compared to I/R saline rats, after the treatment period (These data are summarized in Table 2). 
Table 2 - Data of comparative tests of renal function and C-reactive protein in renal I/R rats treated and untreated with tadalafil

\begin{tabular}{lccc}
\hline \multirow{2}{*}{ Parameters } & \multicolumn{2}{c}{ Groups } & \multirow{2}{*}{ p-value } \\
\cline { 2 - 3 } & I/R Saline & I/R tadalafil & \\
\hline Urea $(\mathbf{m g} / \mathbf{d L})$ & $56.8 \pm 10.06$ & $43.5 \pm 3.2$ & 0.01 \\
Creatinine $(\mathbf{m g} / \mathbf{d L})$ & $0.63 \pm 0.10$ & $0.40 \pm 0.1$ & 0.001 \\
C-reactive Protein $(\mathbf{m g} / \mathbf{d L})$ & $5.4 \pm 014$ & $4.08 \pm 0.24$ & 0.0001 \\
\hline
\end{tabular}

Values in mean \pm standard deviation

\section{DISCUSSION}

Experimental reperfusion following renal ischemia may cause acute inflammation and secondary tissue damage. Development of reactive oxygen species at this stage may increase damage. Endogenous antioxidant enzymes exert protective effects on cells by decreasing the effects of reactive oxygen, and the amounts of antioxidant enzymes differ depending on the severity of the oxidative stress $^{23}$. Vascular endothelial damage develops during renal ischemia ${ }^{24,25}$, while nitric oxide (NO) is released by the renal vascular endothelium, the balance between $\mathrm{NO}$ and endothelin-1 is changed. This decreases the elasticity of the renal vascular endothelium and thus increases vascular resistence $^{25}$.

When sildenafil is administered to $\mathrm{I} / \mathrm{R}$ damaged kidneys during the ischemic phase, I/ R damage was corrected due to reduced leukocyte infiltration ${ }^{26}$. Vardenafil also plays a protective role in I/R damage; however, few studies have addressed the effects of tadalafil on I/R damage $^{21}$. Tadalafil is a vasoactive agent used to treat erectile dysfunction that has a different chemical structure than sildenafil and vardenafi ${ }^{27}$. Tadalafil reaches maximum plasma concentration in 2 hours, and its plasma half-life is four-fold longer (17.5 hours) than those of sildenafil and vardenafil (4 hours) ${ }^{28}$. Because of this prolonged effect, it is considered more advantageous for lowering vascular resistance and treating ischemia. Considering this fact, we opted to measure the laboratory data 24 hours after renal I/R.

Authors examined the effect of tadalafil on renal $\mathrm{I} / \mathrm{R}$ damage and histopathological and total antioxidant capacity changes in tissue ${ }^{21}$. They observed that tadalafil exerted a protective effect on tissues by increasing the antioxidant capacity. Other research similarly observed that blood total antioxidant capacity levels decreased significantly in the I/R group, but that this decrease was prevented by the administration of 
tadalafil 1 hour before ischemia (I/R-Tadalafil group) ${ }^{16}$. We have used the methodological data of this study to decide the injection of tadalafil one hour before the I/R induction .

In the present study, we showed that circulating levels of two key proinflammatory cytokines, TNF-a and IL-1 $\beta$ were significantly reduced after tadalafil treatment. There was a trend towards a reduction in pro-inflammatory cytokines, whereas the anti-inflammatory cytokine IL-10 was significantly higher in tadalafil treated rats compared to I/R saline group. Besides an overall decreased inflammatory profile, we observed that tadalafil improved fasting plasma urea, creatinine and C-reactive protein levels, and our results correlate with previously published data and known physiological pathways ${ }^{15}$.

In conclusion, we have provided evidence that tadalafil therapy ameliorates circulating pro-inflammatory cytokines in renal $\mathrm{I} / \mathrm{R}$ rodent model, while improving renal function proofs levels and reducing C-reactive protein. These results suggest that pretreatment with tadalafil may be a promising therapy for renal protection in kidney $I / R$ patients. Further trials may lead to potential application of tadalafil in clinical practice.

\section{REFERENCES}

1. Simmons MN, Schreiber MJ, Gill IS. Surgical Renal Ischemia: A Contemporary Overview. J Urol. 2008;180:19-30.

2. Foley DP, Chari RS. Ischemia-reperfusion injury in transplantation: novel mechanisms and protective strategies. Transplant Rev. 2007;21:43-53.

3. Desai MM, Gill IS, Ramani AP, Spaliviero M, Rybichi L, Kaouk JH. The impact of warm ischemia on renal function after laparoscopic partial nephrectomy. BJU Int. 2005;95:377-83.

4. Yamaki VN, Gonçalves TB, Coelho JVB, Pontes RVS, Costa FLS, Brito MVH. Efeito protetor do per-condicionamento isquêmico remoto nas lesões da síndrome de isquemia e reperfusão renal em ratos. Rev Col Bras Cir. 2012; 39(6):529-33.

5. Salvadori M, Rosso G, Bertoni E. Update on ischemia-reperfusion injury in kidney transplantation: Pathogenesis and treatment. World J Transplant. 2015:24;5(2):52-67.

6. Riggs SB, LaRochelle JC and Belldegrun AS. Partial nephrectomy: A contemporary review regarding outcomes and different techniques. Cancer J. 2008;14:302-7.

7. Lledo-García E, Rodríguez Martínez D, Cabello Benavente R, Dulín E, García Bordas J, Fernández Álvarez E, Hernández-Fernández C, Del Canizo Lopez JF. Precondicionamiento farmacológico con sildenafilo del riñón con isquemia normotérmica. Actas Urol Esp. 2008;32:67-74

8. Jeong GY, Chung KY, Lee WJ, Kim YS, Sung SH. The effect of a nitric oxide donor on endogenous endothelin-1 expression in renal ischemia-reperfusion injury. Transplant Proc. 2004; 36:1943-5.

9. Derweesh $\mathrm{IH}$, Novick AC. Mechanisms of renal ischaemic injury and their clinical impact. BJU Int. 2005;95:948-50. 
10. Hosgood SA, Bagul A, Kaushik M, Rimoldi J, Gadepalli RS, Nicholson ML. Application of nitric oxide and carbon monoxide in a model of renal preservation. $\mathrm{Br} \mathrm{J}$ Surg. 2008; 95:1060-7

11. Kukreja RC, Salloum F, Das A, Ockaili R, Yin C, Bremer YA, Fisher PW, Wittkamp M, Hawkins J, Chou E, Kukreja AK, Wang X, Marwaha VR, Xi L. Pharmacological preconditioning with sildenafil: basic mechanisms and clinical implications. Vasc Pharmacol. 2005;42:219-32.

12. Öztürk $H$, Aldemir $M$, Büyükbayram $H$, Dokucu $A$, Otçu $S$. The effects of the nitric oxide donor molsidomine prevent in warm ischemia-reperfusion injury of the rat renal - A functional and histophatological study. Int Urol Nephrol. 2001; 32:601-7.

13. Lledo-Garcia E, Rodriguez-Martinez D, Cabello-Benavente R, Moncada-Iribarren I, Tejedor-Jorge A, Dulin E, Hernandez-Fernandez C, Del Canizo-Lopez JF. Sildenafil improves immediate posttransplant parameters in warm-ischemic kidney transplants. Experimental Study. Transplant Proc. 2007;39: 1354-6.

14. Bremer YA, salloum F, Ockaili R, Chou E, Moskowitz WB, Kukreja RC. Sildenafil citrate (viagra) induces cardioprotective effects after ischemia/reperfusion injury in infant rabbits. Pediatr Res. 2005;57:22-7.

15. Medeiros PJ, Villarim Neto A, Lima FP, Azevedo IM, Leão LR, Medeiros AC. Effect of sildenafil in renal ischemia/reperfusion injury in rats. Acta Cir Bras. 2010;25(6):490-7

16. Erol B, Turker T, Tok A, Bektas S, Mungan G, Ozkanli S, Karakas B, Tokgoz H, Akduman B, Mungan A. The protective effects of tadalafil on renal damage following ischemia reperfusion injury in rats. Kaohsiung J Med Sci. 2015;31:454-62.

17. Gulati $P$, Singh N. Neuroprotective effect of tadalafil, a PDE-5 inhibitor, and its modulation by L-NAME in mouse model of ischemia-reperfusion injury. J Surg Res. 2014;186(1):475-83.

18. Koka S, Das A, Salloum FN, Kukreja RC. Phosphodiesterase-5 inhibitor tadalafil attenuates oxidative stress and protects against myocardial ischemia/reperfusion injury in type 2 diabetic mice. Free Radic Biol Med. 2013;60:80-8.

19. Altaş M, Aras M, Meydan S, Nacar E, Ulutaş KT, Serarslan Y, Yılmaz N. Effects of tadalafil on ischemia/reperfusion injury in rat brain. Acta Neurol Belg. 2014;114(1):3340.

20. Yoshinaga R, Kawai Y, Oka M, Fuchikami C, Oyama T. Effect of a single treatment with tadalafil on blood flow in lower urinary tract tissues in rat models of bladder overdistension/emptying and abdominal aorta clamping/release. Eur J Pharmacol. 2015;754:92-7.

21. Guzeloglu M, Yalcinkaya F, Atmaca S, Bagriyanik A, Oktar S, Yuksel O, Fansa I, Hazan $E$. The beneficial effects of tadalafil on renal ischemia-reperfusion injury in rats. Urol Int. 2011;86(2):197-203.

22. Ozdegirmenci O, Kucukozkan T, Akdag E, Topal T, Haberal A, Kayir H, Oter S, Akyol $M$, Uzbay $T$. Effects of sildenafil and tadalafil on ischemia/reperfusion injury in fetal rat brain. J Matern Fetal Neonatal Med. 2011;24(2):317-23.

23. Singh D, Chander V, Chopra K. Protective effect of catechin on ischemia-reperfusion induced renal injury in rats. Pharmacol Rep. 2005;57:70-6.

24. Lien YH, Lai LW, Silva AL. Pathogenesis of renal ischemia/reperfusion injury: lessons from knockout mice. Life Sci. 2003;74:543-52.

25. Willams P, Lopez H, Britt D, Chan C, Ezrin A, Hottendorf R. Characterization of renal ischemia reperfusion injury in rats. J Pharmacol Toxicol Methods. 1997;37:1-7. 
26. Oruc, O, Inci K, Aki FT, Zeybek D, Muftuoglu SF, Kilinc K, et al. Sildenafil attenuates renal ischemia reperfusion injury by decreasing leukocyte infiltration. Acta Histochem. 2010;112:337-44.

27. Sesti C, Florio V, Johnson EG, Kloner RA. The phosphodiesterase-5 inhibitor Tadalafil reduces myocardial infarct size. Int J Impot Res. 2007;19:55-61.

28. Saenz de Tejada I, Angulo J, Cuevas P, Ferna'ndez A, Moncada I, et al. The phosphodiesterase inhibitory selectivity and the in vitro and in vivo potency of the new PDE5 inhibitor Vardenafil. Int J Impot Res. 2001;13:282-90. 